\title{
Nutrient Removal by Chemical Post Treatment with Lime Following the Biological Stage
}

\author{
Nazire Mazlum ${ }^{1 *}$, Bahar İkizoğlu² \\ ${ }^{1}$ Pamukkale University, Engineering Faculty, Environmental Engineering Dept. \\ 32260 Kınıklı Campus 20070 Kınıklı/Denizli, Turkey \\ ${ }^{2}$ Yıldız Technical University, Civil Engineering Faculty, Environmental Engineering Dept. \\ Davutpaşa Campus 342200 Esenler/Istanbul, Turkey
}

Received: 2 May 2017

Accepted: 31 July 2017

\begin{abstract}
The present study aimed the cost-effective removal of nitrogen and phosphorus nutrients, along with organic matter, from biologically pretreated domestic wastewater by chemical post-treatment. To achieve this objective, following the secondary settling biologically pretreated wastewater was subjected to chemical treatment by lime. And thereby we aimed to decrease phosphate, ammonium, and COD concentrations to low levels in the final effluent.

Sewage wastewater was fed into the activated sludge aeration column on a continuous-flow basis. Effluent was withdrawn from the side of the tank with a pump that helped operate the biological stage at a constant hydraulic retention rate under four different flowrate operations. The hydraulic retention time-controlled operation resulted in an almost constant sludge-age operation. This operation avoided nitrification, while the applied retention time was sufficient to convert nitrogen and phosphorus in the raw wastewater into ammonium and orthophosphate forms, respectively, in the biological stage. Following the secondary settling, lime was added to the supernatant and $\mathrm{pH}$ was increased to 10.5. Ammonia nitrogen was removed by air stripping, and removal of phosphate was achieved with chemical precipitation. Applied post chemical treatment by lime also helped decrease the supernatant organic matter content.
\end{abstract}

Keywords: domestic wastewater, activated sludge, sludge age, ammonia stripping, phosphate precipitation

\section{Introduction}

Activated sludge is the common name of the suspended-growth biological processes used for the treatment of domestic and low- to medium-strength industrial wastewater. Activated sludge provides the conversion of organic matter into microbial culture, and

*e-mail: n.mazlum@gmail.com then reproduced biomass is easily separated by gravity settling. Thereby organic matter content is eliminated from the influent. Activated sludge also provides adequate biological pathways for the elimination of nitrogen and phosphorus nutrients from wastewater by applying advance treatment methods [1-7].

The usual forms of phosphorus nutrients found in aquatic environments include orthophosphate, polyphosphate, and organic phosphate. Phosphorus compounds undergo hydrolysis and are converted to 
the orthophosphate form [8], and phosphorus removal up to low limits could be achieved biologically via enhanced biological phosphorus removal or by chemical precipitation following a biological conversion stage where phosphorus is converted to the orthophosphate form. Successful studies reported the chemical precipitation of orthophosphates from sewage using calcium [9-14].

Nitrogen is the other macro nutrient encountered in domestic wastewater discharge [15]. Nitrogen exists in organically bound nitrogen, ammonia, nitrite, and nitrate forms in wastewater [16]. Organically bound nitrogen predominantly exists in urea in domestic wastewater discharges. In wastewater environments, organic nitrogen is readily converted to ammonium nitrogen via biochemical means [17]. Complete removal of nitrogen could be achieved biochemically via nitrification/denitrification in an activated sludge process, by which ammonia is first oxidized to nitrate and then reduced to nitrogen gas [1822]. Alternatively, ammonium nitrogen can be converted to the ammonia nitrogen form by $\mathrm{pH}$ adjustment and then removed by ammonia stripping method [23]. Biological methods are generally employed to nitrogen removal from wastewater. Organic nitrogen compounds are broken down by organisms into ammonium. Some of the ammonia is assimilated by organisms and converted to cellular proteins while the other part is first converted to nitrite and then nitrate by "nitrification bacteria," a process called "nitrification." The conversion of nitrate ions to nitrite and then to nitrogen $\left(\mathrm{N}_{2}\right)$ by denitrification bacteria is expressed as "denitrification." Thus, nitrogen removal from wastewater is provided by biologically sequential nitrification and denitrification steps [24-25].

Organic matter removal can be achieved at high efficiencies in low-loaded (extended) biological aeration systems [26]. However, the high oxygen demand required for high-degree biological conversion makes the process costly [27-28]. On the other hand, in high-loaded systems, adsorption of colloidal organic matter onto mixed-liquor suspended-solids (MLSS) significantly contributes to the removal of organic matter via the biological pathway [29]. The colloidal organic substances adsorbed on MLSS are removed by settling in the secondary settling tank. The contribution of adsorption to removal is high in highloaded systems, and thus decreases the oxygen demand considerably. However, as a disadvantage, low effluent organic matter concentration limits may not be achieved in high-loaded systems. Hence a further biological or physicochemical post-treatment may be required to achieve the desired low-effluent organic matter limits [30-32].

In the present study, an activated sludge system was operated on a continuous-flow basis with high sludge load rates where bound phosphorus and nitrogen forms were converted to orthophosphate and ammonium nitrogen, respectively, at a high degree, while nitrification was not allowed to take place. We aimed to remove orthophosphates by chemical precipitation and ammonium nitrogen in ammonia gas form by air stripping in the effluent (supernatant) of the secondary settling tank. In the study, loading rate applied to biological stage was sufficient to convert bound nitrogen and phosphorus to ammonia and orthophosphate forms at a high level, while loading rate was high enough to prevent nitrification. Lime was added into the samples taken from the supernatant in the secondary settling tank. $\mathrm{pH}$ was increased to 10.5 and the resultant removal of ammonia nitrogen by stripping during the mixing period in the jar test apparatus, phosphate precipitation, and the removal of organic matter by lime-coagulation were investigated.

The objective of the present study was to investigate cost-effective removal of nitrogen and phosphorus nutrients, along with organic matter, from biologically pretreated domestic using chemical post-treatment. To achieve this purpose, biologically pretreated wastewater following the secondary settling was exposed to chemical treatment by lime. Thus, it was aimed to decrease phosphate, ammonium, and COD concentrations to low levels in the final effluent.

\section{Material and Methods}

The wastewater was obtained from sewage and allowed to settle in a tank under quiescent conditions for half an hour, and then supernatant was transferred to the feed reservoir. The average raw wastewater properties measured in the feed reservoir during the test period are given in Table 1. The observations presented in Table 1 display the maximum, minimum, and mean daily measurements that were conducted during the test period. The wastewater in the feed reservoir was continuously agitated during the study with diffused air aeration, to both maintain homogenous conditions in the feed supply and prevent the development of anoxic/anaerobic conditions in the reservoir. The wastewater was pumped into the biological aeration column on a continuousflow basis. The feed reservoir volume was replenished with fresh pre-settled wastewater, as mentioned above, at intervals during the operational period. The feed reservoir was kept under ambient temperature conditions where wastewater temperature ranged between $15^{\circ} \mathrm{C}$ and

Table 1. Wastewater properties measured in the feed reservoir during the study.

\begin{tabular}{|c|c|c|c|}
\hline Quality variable & Max. value & $\begin{array}{l}\text { Min. } \\
\text { value }\end{array}$ & $\begin{array}{l}\text { Mean } \\
\text { value }\end{array}$ \\
\hline COD (mg/L) & 295 & 224 & 255 \\
\hline $\mathrm{BOD}_{5}(\mathrm{mg} / \mathrm{L})$ & 185 & 158 & 172 \\
\hline $\mathrm{TP}(\mathrm{mg} / \mathrm{L})$ & 6.5 & 4.2 & 5.4 \\
\hline $\mathrm{PO}_{4}-\mathrm{P}(\mathrm{mg} / \mathrm{L})$ & 4.6 & 2.8 & 3.8 \\
\hline TKN (mg/L) & 38 & 26 & 32 \\
\hline $\mathrm{NH}_{4}-\mathrm{N}(\mathrm{mg} / \mathrm{L})$ & 17 & 29 & 24 \\
\hline $\begin{array}{c}\mathrm{NO}_{3}-\mathrm{N} \text { and } \mathrm{NO}_{2}-\mathrm{N} \\
(\mathrm{mg} / \mathrm{L})\end{array}$ & $\begin{array}{c}\text { not } \\
\text { detectable }\end{array}$ & & \\
\hline $\mathrm{pH}$ & 6.7 & 7.3 & 7.1 \\
\hline
\end{tabular}


$17^{\circ} \mathrm{C}$. All the tests in the study were conducted at ambient conditions that ranged between $21^{\circ} \mathrm{C}$ and $23.5^{\circ} \mathrm{C}$.

The experimental setup included a biological aeration unit and a secondary settling tank. The aeration tank was a cylindrical column with $0.16 \mathrm{~m}$ inner diameter. Water depth in the column was altered based on the applied flowrate to maintain $2.6 \mathrm{~h}$ hydraulic retention time for each test flowrate. Effluent from the biological column was withdrawn using a variable-speed pump on a continuousflow basis. Fine bubble aeration through a rubber diffuser was applied for biological oxygenation. The biological reactor was ideally operated under completely mixed stirred-tank conditions.

Before starting the tests, activated sludge biomass was reproduced in the system (Fig. 1). For the reproduction of activated sludge microbial culture, wastewater was pumped into the aeration column at a $2 \mathrm{~L} / \mathrm{h}$ fixed flowrate on a continuous-flow basis. The hydraulic retention time was adjusted to $3 \mathrm{~h}$ in the column, corresponding to a 0.3 $\mathrm{m}$ water column head. The mixed-liquor was withdrawn from the side of the biological reactor by a pump at the same flowrate as influent flowrate on a continuous-flow basis. Then effluent from the biological reactor was allowed to settle and separate in the secondary settler for two hours of hydraulic retention time. The effluent supernatant from the settler was discharged and the settled sludge was recycled to the biological aeration column on a continuous-flow basis.

Bio-kinetic parameters were determined using the same setup depicted in Fig. 1, for which the system was operated on a continuous-flow basis without the sludge recycle. Six different hydraulic retention times were tested to determine the biological system kinetic constants under ambient temperature conditions. Hydraulic retention time was adjusted by maintaining the required water column head in the column.

At first, tank volume (water column head) was adjusted to the desired level to maintain the required hydraulic retention time $(3 \mathrm{~h})$, and then MLSS concentration in the biological stage was increased to about $1,200 \mathrm{mg} / \mathrm{L}$ with biomass reproduction, which was achieved by applying continuous-flow operation with the sludge recycle. Following the reproduction period, sludge recycle was stopped and tests were initiated to determine the biokinetic parameters. During the tests, mixed-liquor samples that were withdrawn from the aeration column at certain intervals were filtered. Filtrates were analyzed for COD concentration, and thereby steady-state was detected. When the steady-state was observed for $\mathrm{COD}, \mathrm{BOD}_{5}$, and MLSS, the concentrations were measured and the single flowrate test operation was terminated. It was assumed that steady-state COD concentration approximately indicated that $\mathrm{BOD}_{5}$ concentration was also at a steadystate. The test operations were repeated for six different flowrates. Using CFSTR operational mode and steadystate operational conditions, kinetic parameters were determined with the mass balance equations as outlined in the appendix. In mass-balance equations, the Monod model was applied for biomass growth and the resulting model constants were determined.

Following determination of the kinetic constants, operational tests for nutrient removal were conducted for three different flowrates. The hydraulic retention time was kept constant by maintaining the required water column head in the column for each test operation. In other words, hydraulic retention time was kept constant at each flow operation by adjusting the water column head. The mixed-liquor suspended solids were withdrawn from the biological column with a peristaltic pump at flowrates equal to the influent flowrate. The constant hydraulic retention time operation aimed at an almost constant sludge age operation, to the attainable extent, to avoid nitrification [33]. We observed $\mathrm{BOD}_{5}$ removal as well as ammonium nitrogen and orthophosphate formation ratios in the biological reactor in the tested relatively short hydraulic retention times. At each operation, MLSS

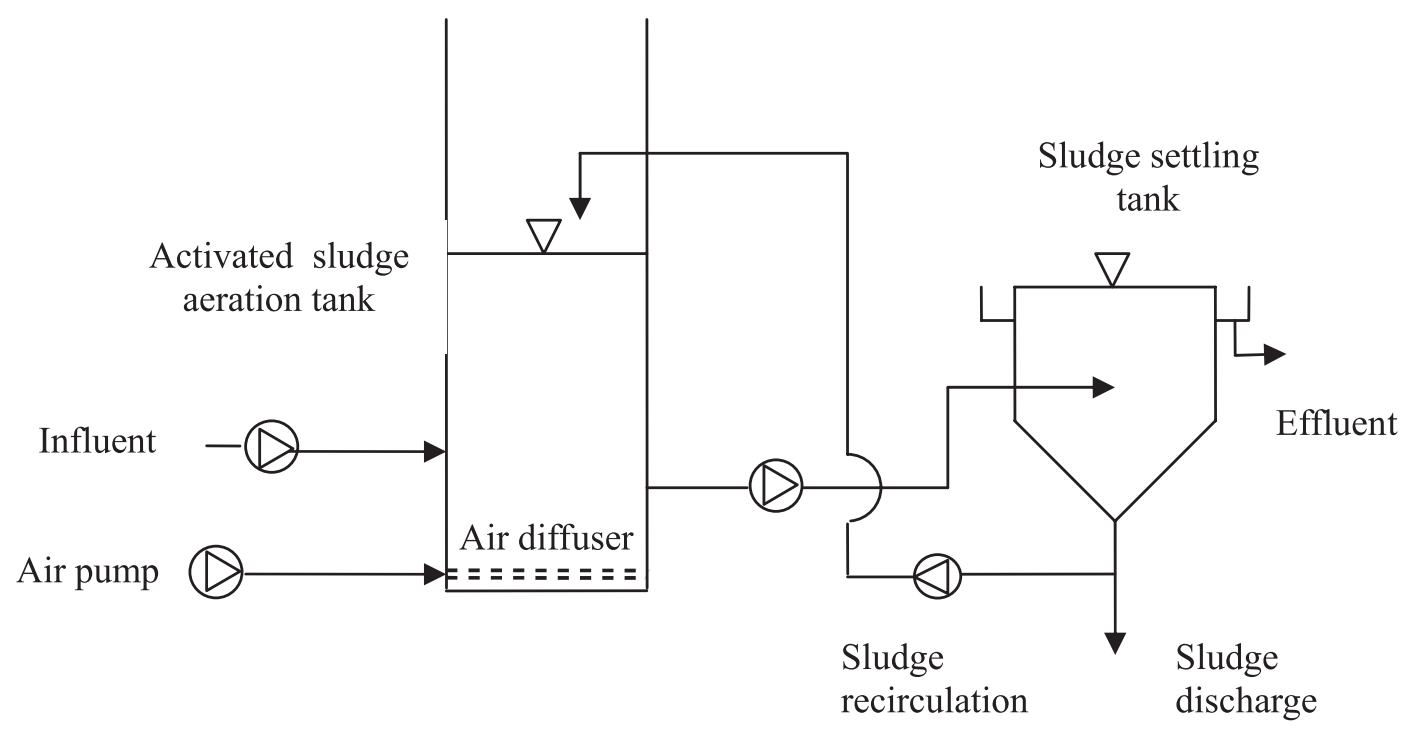

Fig. 1. Setup for biomass reproduction, determining kinetic parameters, and biological operation. 
concentration in the biological reactor was maintained at around $3,000 \mathrm{mg} / \mathrm{L}$ by sludge recirculation. Computed sludge ages in the system considered only the sludge mass in the biological reactor. Effluent quality properties given in tables reflect the steady-state conditions for each test operation.

The mixed-liquor suspended solid samples taken under steady-state operational conditions were filtered, and filtrates were analyzed for organic matter, suspended matter, nitrogen, and phosphorus concentrations. Filtrates were then subjected to post-chemical treatment, for which lime was added to the filtrates and $\mathrm{pH}$ was increased to 10.5. The volume of the filtrates that were subjected to chemical processing was $500 \mathrm{~mL}$ for each test. The lime dosage aimed to: 1) convert ammonium ions to ammonia gas, 2) remove phosphate with calcium ions as precipitate, and 3) remove $\mathrm{BOD}_{5}$ to a certain extent by lime-coagulation. The lime-added filtrates were agitated in a jar test apparatus (VELP JLT6) for $5 \mathrm{~min}$ at $200 \mathrm{rpm}$ and subsequently for $30 \mathrm{~min}$ at $30 \mathrm{rpm}$. Then the samples were allowed to settle for two hours for gravity separation. Following settling, supernatant concentrations were analyzed.

\section{Analysis Methods}

To determine phosphorus content, samples were analyzed for orthophosphates using the ascorbic acid colorimetric method on a spectrophotometer at $880 \mathrm{~nm}$ (Novaspec II). Total phosphorus content was determined by following the acidic digestion of the samples at $450^{\circ} \mathrm{C}$. Following the $\mathrm{pH}$ adjustment, absorbance was measured with the ascorbic acid colorimetric method using a Novaspec II spectrophotometer at $880 \mathrm{~nm}$ wavelength.

To determine the sample nitrogen content, samples were initially analyzed for ammonium nitrogen content using the Nessler method with a spectrophotometer (HACH DR/2000). Then, bound nitrogen was digested to ammonium nitrogen in a TKN distillator (Selecta ProNitro II) and then total ammonium nitrogen (TKN) was determined. Nitrate and nitrite analyses were conducted with a spectrophotometer (HACH DR/2000).

\section{Results and Discussion}

\section{Determining Kinetic Parameters}

Each substrate and MLSS concentration measurement given in Table 2 reflects the steady state system operation. Biological column effluents were analyzed for MLSS (X) and effluent filtrates were analyzed for COD and $\mathrm{BOD}_{5}$ (S) concentrations. The applied flowrates and observed S and $\mathrm{X}$ concentrations in the effluent are presented in Table 2, which also outlines the computed data for determining kinetic parameters: column (1) shows the number of tests; column (2) indicates the flowrate into and out of the column; columns (3) and (4) indicate the water column heads and resulting hydraulic retention times in the aeration column; columns (5) and (6) indicate the effluent MLSS concentration and filtrate $\mathrm{BOD}_{5}$ concentration; and columns (7), (8), (9), and (10) indicate the computed parameters.

The computed data in Table 2 were utilized to estimate $\mathrm{Y}$ and $\mathrm{k}_{\mathrm{d}}$ parameters in the regression equation form as given in Eq. 1.

$$
\frac{1}{\theta}=Y \cdot \frac{\left(S_{0}-S\right)}{\theta \cdot X}-k_{d}
$$

In Fig. 2, the derived linear equation is drawn using the data given in Table 2. From the derived regression equation line, $\mathrm{Y}$ and $\mathrm{k}_{\mathrm{d}}$ parameter values were found to be 0.556 and 0.055 day $^{-1}$, respectively.

Computed data in Table 2 was also utilized for determining two other kinetic unknowns, $K_{s}$ and $\mu_{\max }$. A plot of $\frac{\theta . X}{Y .\left(S_{0}-S\right)}$ gives $K_{s}$ and $\mu_{\max }$ parameter values in regression form as in Eq. (2).

$$
\frac{\theta \cdot X}{Y .\left(S_{0}-S\right)}=\frac{K s}{\mu_{\max }} \cdot \frac{1}{S}+\frac{1}{\mu_{\max }}
$$

Using the data given in Table 2, the regression line obtained is given in Fig. 3.

\begin{tabular}{|c|c|c|c|c|c|c|c|c|c|}
\hline & \multicolumn{5}{|c|}{ Observed data } & \multicolumn{4}{|c|}{ Computed data } \\
\hline $\begin{array}{l}\text { Test } \\
\text { No. }\end{array}$ & $\begin{array}{c}\mathrm{Q} \\
\mathrm{L} / \text { day }\end{array}$ & $\begin{array}{l}\mathrm{h} \\
\mathrm{m}\end{array}$ & $\begin{array}{c}\theta \\
\text { day }\end{array}$ & $\begin{array}{c}\mathrm{X} \\
\text { mgMLSS/L }\end{array}$ & $\frac{\mathrm{S}}{\mathrm{mgBOD}_{5} / \mathrm{L}}$ & $1 / \theta$ & $\left(S_{0}-S\right) /\left(\theta^{*} \mathrm{X}\right)$ & $\left(\theta^{*} \mathrm{X}\right) / \mathrm{Y} *\left(S_{0}-S\right)$ & $1 / \mathrm{S}$ \\
\hline (1) & (2) & (3) & (4) & (5) & (6) & (7) & (8) & (9) & $(10)$ \\
\hline 1 & 20 & 0.60 & 0.6 & 85.5 & 114 & 1.666 & 3.079 & 0.582 & 0.008 \\
\hline 2 & 20 & 0.80 & 0.8 & 117 & 53,5 & 1.250 & 2.334 & 0.768 & 0.018 \\
\hline 3 & 20 & 1.00 & 1.0 & 126 & 35 & 1.000 & 1.880 & 0.953 & 0.028 \\
\hline 4 & 20 & 1.20 & 1.2 & 129 & 26,5 & 0.833 & 1.585 & 1.130 & 0.037 \\
\hline 5 & 20 & 1.40 & 1.4 & 130.5 & 21 & 0.714 & 1.373 & 1.305 & 0.047 \\
\hline 6 & 20 & 1.60 & 1.6 & 131 & 18 & 0.625 & 1.211 & 1.479 & 0.055 \\
\hline
\end{tabular}

Table 2. Operational system data for determining kinetic parameters. 


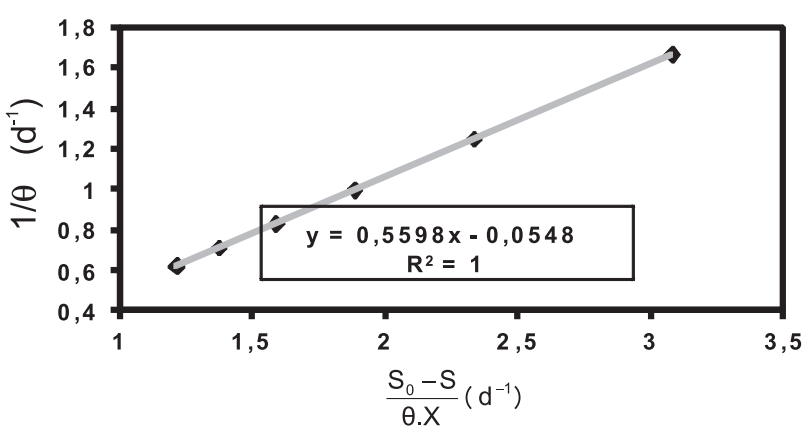

Fig. 2. Estimation of $\mathrm{k}_{\mathrm{d}}$ and $\mathrm{Y}$ parameters using the derived regression line.

From the derived regression line, $\mu_{\max }$ and $\mathrm{K}_{\mathrm{s}}$ parameters were found as 3.16 day $^{-1}$ and $56 \mathrm{mg} / \mathrm{L}$, respectively.

\section{Operational Tests at Constant Hydraulic Retention Time}

It was the aim of our study to operate the system at a constant sludge age to control nitrification. To achieve this goal in the operated system in a practical way, hydraulic retention time in the biological reactor was maintained at a constant at $2.6 \mathrm{~h}$ and applied to four different flowrates, and the resulting practical and theoretical sludge ages were calculated. The principal aim of almost constant sludge age operation was to simulate the previously published system [33], which aimed to maintain constant hydraulic retention time under different flowrates resulting in different water depths (water column heads) in the aeration channel. At the implemented four different flowrates, MLSS concentrations in the biological column were maintained at around $3,000 \mathrm{mg} / \mathrm{L}$. Average MLSS concentrations in the recycled sludge were around 6,800 $\mathrm{mg} \mathrm{MLSS} / \mathrm{L}$ with slight deviations. The operation for a single flowrate lasted until steady state was achieved for the filtered effluent COD concentration. When COD did not exhibit any further changes in time we analyzed the $\mathrm{BOD}_{5}$ parameter. The resultant operational biological system parameters for the tested four flowrates are given in Table 3 .

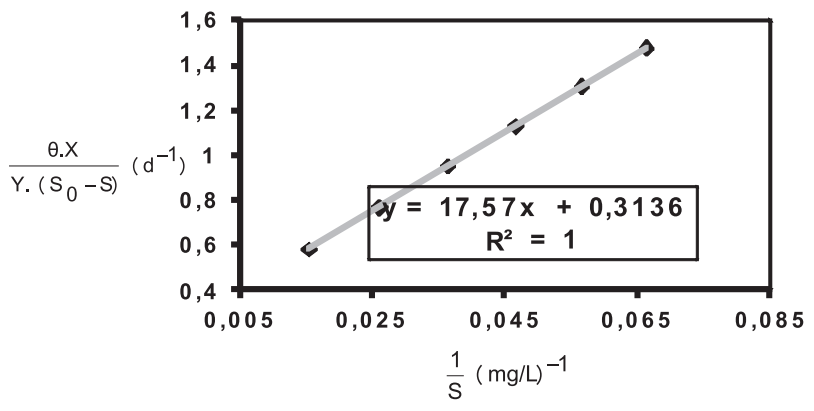

Fig. 3. Estimating $\mathrm{K}_{\mathrm{s}}$ and $\mu_{\max }$ parameters using the derived regression line.
Table 3. Operational parameters obtained at ambient temperature conditions.

\begin{tabular}{|c|c|c|c|c|}
\hline Test No & $\begin{array}{c}\mathrm{Q} \\
(\mathrm{L} / \mathrm{d})\end{array}$ & $\begin{array}{c}\mathrm{h} \\
(\mathrm{m})\end{array}$ & $\begin{array}{c}\mathrm{Q}_{\mathrm{r}} \\
(\mathrm{L} / \mathrm{d})\end{array}$ & $\begin{array}{c}\mathrm{Q}_{\mathrm{w}} \\
(\mathrm{L} / \mathrm{day})\end{array}$ \\
\hline 1 & 20 & 0.11 & 15 & 1.1 \\
\hline 2 & 30 & 0.16 & 20 & 1.4 \\
\hline 3 & 40 & 0.21 & 28 & 1.8 \\
\hline 4 & 50 & 0.27 & 35 & 2.4 \\
\hline
\end{tabular}

The theoretical sludge age depicted in Table 3 was computed by considering the amount of biomass in the biological reactor. Operational sludge age was computed by dividing the amount of biomass in the biological reactor by the amount of biomass wasted daily as given below.

$$
\theta_{c}=\frac{X \cdot \forall}{Q w \cdot X r}
$$

Considering that the biological system in the test conditions was a completely mixed continuous-flow reactor, the mass balance solution of the system for biomass under steady-state conditions results as shown in Eq. 4. This equation was used to compute the theoretical sludge age in the system.

$$
\frac{1}{\theta_{c}}=\mu_{\max } \cdot \frac{S}{K S+S}-k_{d}
$$

In the system operation, both practical and theoretical sludge age were identified to be about 1 day without significant deviations for four different flowrate tests.

$1 \mathrm{~L}$ mixed-liquor sample was taken from the aeration column at each operation under steady state and then allowed to settle in the beaker for $2 \mathrm{~h}$. At the end of the settling period, $250 \mathrm{~mL}$ settled mixed-liquor supernatant was further filtered through $0.45 \mu \mathrm{m}$ pore-sized cellulose-acetate filter membrane and then filtrates were analyzed for $\mathrm{TP}, \mathrm{PO}_{4}-\mathrm{P}, \mathrm{TKN}, \mathrm{NH}_{4}-\mathrm{N}$, and $\mathrm{BOD}_{5}$ concentrations. The results are given in Table 4.

Table 4. Biological reactor effluent quality.

\begin{tabular}{|c|c|c|c|c|c|c|}
\hline $\begin{array}{c}\text { Test } \\
\text { No. }\end{array}$ & $\begin{array}{c}\mathrm{Q} \\
(\mathrm{L} / \mathrm{d})\end{array}$ & $\begin{array}{c}\mathrm{BOD}_{5} \\
\text { out }\end{array}$ & $\begin{array}{c}\mathrm{TKN} \\
\text { out }\end{array}$ & $\begin{array}{c}\mathrm{NH}_{4}-\mathrm{N} \\
\text { out }\end{array}$ & $\begin{array}{c}\mathrm{TP} \\
\text { out }\end{array}$ & $\begin{array}{c}\mathrm{PO}_{4}-\mathrm{P} \\
\text { out }\end{array}$ \\
\hline 1 & 20 & 75 & 20 & 16 & 4.5 & 4.1 \\
\hline 2 & 30 & 68 & 16 & 14 & 3.8 & 3.3 \\
\hline 3 & 40 & 72 & 15 & 12 & 4.1 & 3.7 \\
\hline 4 & 50 & 66 & 18 & 15 & 4.0 & 3.5 \\
\hline
\end{tabular}


Table 5. Supernatant quality following chemical post-treatment.

\begin{tabular}{|c|c|c|c|c|c|c|}
\hline $\begin{array}{c}\text { Test } \\
\text { No. }\end{array}$ & $\begin{array}{c}\mathrm{Q} \\
(\mathrm{L} / \mathrm{d})\end{array}$ & $\mathrm{BOD}_{5}$ & $\mathrm{TKN}$ & $\mathrm{NH}_{4}-\mathrm{N}$ & $\mathrm{TP}$ & $\mathrm{PO}_{4}-\mathrm{P}$ \\
\hline 1 & 20 & 35 & 5.2 & 2.9 & 1.5 & 1.2 \\
\hline 2 & 30 & 28 & 5.5 & 3.4 & 1.8 & 1.3 \\
\hline 3 & 40 & 22 & 5.8 & 3.2 & 1.3 & 1.1 \\
\hline 4 & 50 & 36 & 6.1 & 3.8 & 1.4 & 1.2 \\
\hline
\end{tabular}

\section{Physicochemical Post-Treatment}

In this stage, $0.5 \mathrm{~L}$ supernatant of the settled samples was transferred to another beaker, and lime in the form of $\mathrm{Ca}(\mathrm{OH})_{2}$ was added into the beakers, resulting in a $\mathrm{pH}$ of about 10.5. The amounts of lime added to $0.5 \mathrm{~L}$ filtrates were $1.80,1.85,1.85$, and $1.95 \mathrm{~g} \mathrm{Ca}(\mathrm{OH})_{2}$, for Test 1 , Test 2 , Test 3, and Test 4 samples, respectively. Consequently, the samples were mixed in a jar test apparatus for $5 \mathrm{~min}$ at $200 \mathrm{rpm}$, and subsequently for $30 \mathrm{~min}$ at $50 \mathrm{rpm}$. Subsequently, the suspension was allowed to settle for $2 \mathrm{~h}$. Then, $250 \mathrm{~mL}$ supernatant was filtered through a $0.45-\mu \mathrm{m}$ pore-sized cellulose-acetate filter membrane, and the filtrate was analyzed for $\mathrm{TP}, \mathrm{PO}_{4}-\mathrm{P}, \mathrm{TKN}, \mathrm{NH}_{4}-\mathrm{N}$, and $\mathrm{BOD}_{5}$ concentrations. The results are given in Table 5.

Traditionally, technologies such as biological and chemical treatment for phosphate or nitrate have been widely used [34]. Recently, the synthesis and performance of iron oxide-based porous ceramsite in a biologically aerated filter were used for the simultaneous removal of nitrogen and phosphorus from domestic wastewater [35]. [36] studied phosphorus removal efficiency in sediment samples collected from the outlet of the Yangtze River and found higher removal efficiency (60-89\%) for phosphorus after modified conditions with iron.

In another study, generally high rates (more than $80 \%$ of organic substances and $90 \%$ of phosphorus removal) could succeed with the chemical addition in sewage treatment [37]. The chemical treatability of sewage water was investigated by performing a series of experiments on sewage water taken from Baltalimani Mechanical Treatment Plant in Istanbul.

A second study [38] investigated the performance of chemical precipitation on soluble and particulate contaminants in municipal wastewater by chemical precipitation. For this aim, they used alum, ferric salts, and lime at optimal dosages to the effluent samples collected from Baltalimani and Yenikapi preliminary wastewater treatment plants, which are two of the major wastewater treatment plants in Istanbul. Particulate COD removal efficiency was $90 \%$ around optimal dosage except for lime, for both of the wastewaters. If lime is used, the removal efficiency for the particulate COD was lower than the other chemicals. Soluble TP removal efficiency was more than $93 \%$ for both of the wastewaters, but particulate TP removal efficiency was $60-77 \%$ and less than $50 \%$ for Yenikapi and Baltalimani wastewaters, respectively. Particulate TKN removal efficiency was about $80 \%$ for both wastewaters. However, the removal efficiency of soluble TKN was lower than $20 \%$.

\section{Conclusions}

The results indicated that high-loaded activated sludge systems offer relatively high organic matter removal in short hydraulic retention times as compared to long hydraulic retention times in low-loaded systems. The high removal is attributed to adsorption of organic colloidal particles on mixed-liquor suspended solids, which are removed by settling in the secondary settling tank. Lime coagulation applied to the supernatant in the secondary settler decreased organic matter concentration in the supernatant to acceptable low levels.

Applied hydraulic retention time, or sludge age, provided the conversion of bound nitrogen and phosphorus forms into inorganic forms at high efficiency. The high conversion efficiencies obtained under the applied relatively short hydraulic retention times are attributed to microbial activities that were present in the biological reactor. Applied high organic load rates prevented nitrification, and thereby almost all the nitrogen remained in ammonia form in the biological reactor effluent.

Lime treatment of the supernatant in the secondary settler provided successful removal of ammonia during the mixing period (aeration period) in a jar test apparatus. The addition of lime also resulted in orthophosphate removal, possibly by chemical precipitation, resulting in low supernatant phosphorus limits.

\section{Appendix. Determining Kinetic Parameters}

The completely mixed system with the displayed boundaries is shown below.

It is clear that in the above system, in completely mixed flow conditions, the hydraulic detention time of solid particles, $\theta_{c}$, will be equal to the detention time of the water molecules, $\theta$, due to the thorough mixing effect in the tank. Hence, if sludge recirculation from the settling tank to the biologically active tank is not applied, then the statement given in Eq. A1 is utilized.

$$
\theta=\theta_{c}
$$

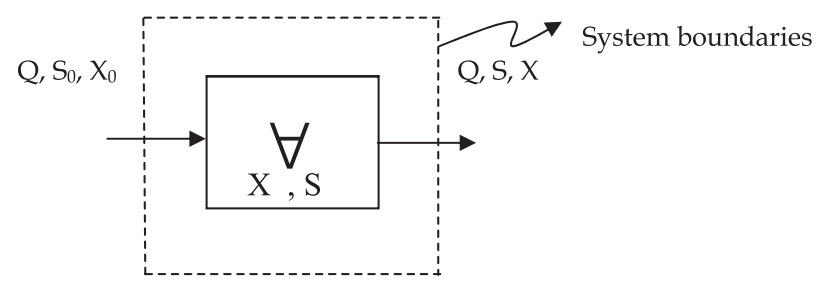

Fig. 4. Completely-mixed continuous-flow reactor. 
For the above system, the mass balance for the microorganisms can be written as below:

$$
\frac{d X}{d t} . \forall=Q \cdot X_{0}-Q \cdot X+r_{x}^{\prime} \cdot \forall
$$

If all the terms in Eq. A2 are divided by volume, the following statement is obtained:

Considering that the raw wastewater influx from the sewage system does not include the type of microorganisms that are active in a biological conversion process in the tank, the concentration of microorganism $X_{0}$ in raw wastewater is accepted as zero. Additionally, if all terms in Eq. A1 are divided by $\forall$, and the $\frac{\forall}{Q}$ ratio is indicated by hydraulic retention time $\theta$ under continuousflow conditions, then Eq. A2 takes the following form:

$$
\frac{d X}{d t}=\frac{1}{\theta} \cdot X_{0}+r_{x}^{\prime}
$$

Net growth rate in biological systems is expressed as follows:

$$
r_{x}^{\prime}=\mu \cdot X-k_{d} \cdot X
$$

Considering that under steady-state operational conditions microorganism concentration gradient with respect to time, $\frac{d X}{d t}$, is zero, then embedding Eq. A4 in Eq. A3 gives the following equation for steady-state operational conditions:

$$
\frac{1}{\theta}=\mu-k_{d}
$$

The substrate $\left(\mathrm{BOD}_{5}\right)$ mass balance statement on the system boundaries for Fig. 2 is:

$$
\frac{d S}{d t} \cdot \forall=Q \cdot S_{0}-Q \cdot S+r_{s} \cdot \forall
$$

In a biological system, microorganism growth is the result of substrate utilization (depletion), as expressed in Eq. A7:

$$
\frac{d X}{d t}=-Y \cdot \frac{d S}{d t}
$$

...in which microorganism growth rate based on the microbial population is expressed as shown in Eq. A8:

$$
\frac{d X}{d t}=\mu \cdot X
$$

If Eq. A8 is embedded in Eq. A7 and $\frac{d S}{d t}$ term is indicated by the $r_{s}$ symbol, then Eq. A7 can be reorganized as shown in Eq. A9:

$$
r_{s}=-\frac{\mu \cdot X}{Y}
$$

If Eq. A9 is embedded in Eq. A6 and rearranged for steady-state operational conditions, where $\frac{d S}{d t}$ will be zero, then the following expression is obtained:

$$
\mu=\frac{Y \cdot\left(S_{0}-S\right)}{\theta \cdot X}
$$

If Eq. A10 is replaced in Eq. A5, then the following equation is obtained in arranged form:

$$
\frac{1}{\theta}=Y . \frac{\left(S_{0}-S\right)}{\theta \cdot X}-k_{d}
$$

A plot of $\frac{1}{\theta}$ versus $\frac{S_{0}-S}{\theta \cdot X}$ gives a straight line. The slope of the line gives $Y_{x}$ and intercept gives $k_{d}$ values.

Growth rate $\mu$ is the most commonly expressed by the Monod model as given in Eq. A12:

$$
\mu=\mu_{\max } \cdot \frac{S}{K_{S}+S}
$$

If the Monod-type growth model is utilized to model biological growth, then the Monod model constants can be determined. For that purpose, Eq. A12 is embedded in Eq. A10 and reorganized as given in Eq. A13 in a linear form:

$$
\frac{\theta \cdot X}{Y .\left(S_{0}-S\right)}=\frac{K_{S}}{\mu_{\max }} \cdot \frac{1}{S}+\frac{1}{\mu_{\max }}
$$

A plot of $\frac{\theta . X}{Y .\left(S_{0}-S\right)}$ versus $\frac{1}{S}$ gives $\mathrm{K}_{\mathrm{s}}$ and $\mu_{\max }$ Monod kinetic constants as slope and intercept of the derived regression line.

\section{Notations}

Q flowrate, $\mathrm{L}^{3} \cdot \mathrm{T}^{-1}$

$\forall \quad$ tank volume, $\mathrm{L}^{3}$

$\mathrm{S}_{0} \quad$ influent substrate concentration, M.L-3

$\mathrm{S} \quad$ effluent substrate concentration, $\mathrm{M} . \mathrm{L}^{-3}$

$\mathrm{X}_{0} \quad$ influent biomass concentration, M.L-3

$\mathrm{X}$ effluent biomas concentration, $\mathrm{M} . \mathrm{L}^{-3}$

$\theta \quad$ hydraulic retention time, $\mathrm{T}$

$\theta_{c} \quad$ sludge age, $\mathrm{T}$

$r_{x} \quad$ net growth rate, $\mathrm{M} . \mathrm{L}^{-3} \cdot \mathrm{T}^{-1}$

$r_{s} \quad$ substrate conversion rate, $\mathrm{M} \cdot \mathrm{L}^{-3} \cdot \mathrm{T}^{-1}$

$\mu \quad$ specific growth rate, $\mathrm{T}^{-1}$

$\mu_{\max } \quad$ maximum specific growth rate, $\mathrm{T}^{-1}$

$\mathrm{k}_{\mathrm{d}} \quad$ decay rate, $\mathrm{T}^{-1}$

$\mathrm{Y}$ yield factor 


\section{Acknowledgements}

The authors would like to thank Süleyman Demirel University and Assoc. Prof. Dr. Süleyman MAZLUM, for supporting this study, and we express our great sorrow over his death on 12.09.2010. He was a great scientist and at the same time he was a great person with humanity and warm kindness to all of us.

\section{References}

1. INYANG M., FLOWERS R., MCAVOY D., DİCKENSON, E. Biotransformation of trace organic compounds by activated sludge from a biological nutrient removal treatment system. Bioresource Technology 216, 778, 2016.

2. GUO J., NI B.-J., HAN X., CHEN X., BOND P., PENG Y., YUAN Z. Unraveling microbial structure and diversity of activated sludge in a full-scale simultaneous nitrogen and phosphorus. Enzyme and Microbial Technology 102, 16, 2017.

3. HONG J.M., HU M.-M., SUN R., CHEN B.Y. Unraveling characteristics of nutrient removal and microbial community in a novel aerated landscape - Activated sludge ecological system. Bioresource Technology 21, 280, 2016.

4. LU Q., WU H., LI H., YANG D. Enhanced biological nutrient removal in modified carbon source division anaerobic anoxic oxic process with return activated sludge pre-concentration. Chinese Journal of Chemical Engineering 23, 1027, 2015.

5. YAN P., GUO J.S., WANG J., CHEN Y.P., JI F.Y., DONG Y., ZHANG H., OUYANG W.J. Enhanced nitrogen and phosphorus removal by an advanced simultaneous sludge reduction, inorganic solids separation, phosphorus recovery, and enhanced nutrient removal wastewater treatment process. Bioresource Technology 183, 181, 2015.

6. HU D., ZHOU Z., NIU T., WEI H., DOU W., JIANG L.-M., LV Y. Co-treatment of reject water from sludge dewatering and supernatant from sludge lime stabilization process for nutrient removal: A costeffective approach. Separation and Purification Technology 172, 357, 2017.

7. YAN P., JI F., WANG J., FAN J., GUAN W., CHEN Q. Evaluation of sludge reduction and carbon source recovery from excess sludge by the advanced Sludge reduction, Inorganic solids separation, Phosphorus recovery, and Enhanced nutrient Removal (SIPER) wastewater treatment process. Bioresource Technology 150, 344, 2013.

8. ZHIMIAO Z., XINSHANS S., YANPING X., YUFENG Z., ZHIJIEG.,FANDA L., YI D., WEI W., TIANGLING Q. Influences of seasons $\mathrm{N} / \mathrm{P}$ ratios and chemical compounds on phosphorus removal performence in algal pond combined with constructed wetlands. Science of the total Environment 573, 906, 2016.

9. ANGEL R. Removal of phosphate from sewage as amorphous calcium phosphate. Environmental Technology 20, 709, 1999.

10. BASHAN L.E., BASHAN Y. Recent advances in removing phosphorus from wastewater and its future use as fertilizer (1997-2003), Water Research 38 (19), 4222, 2004.

11. CARLSSON H., ASPEGREN H., LEE N., HILMER A. Calcium phosphate precipitation in biological phosphorus removal systems. Water Research 31 (5) 1047, 1997.

12. HOUSE W.A. The physico-chemical conditions for the precipitation of phosphate with calcium. Environmental Technology 20, 727, 1999.
13. PLANT L.J., HOUSE W.A. Precipitation of calcite in the presence of inorganic phosphate. Colloids and Surfaces A: Physicochemical and Engineering Aspects 203 (1-3), 143, 2002.

14. YIGIT N., MAZLUM S. Phosphate recovery potential from wastewater by chemical precipitation at batch conditions. Environmental Technology. 28, 83, 2007.

15. WEI D., ZHANG K., NGO H.H., GUO W., WANG S., LI J., HAN F., DU B., WAI Q. Nitrogen removal via nitrite in a partial nitrification sequencing batch biofilm reactor treating high strenght ammonia wastewater and its greenhouse gas emission. Bioresource Technology 230, 49, 2017.

16. JENKINS D. The Analysis Of Nitrogen Forms in Waters And Wastewaters. Proceedings of the Conference on Nitrogen As a Water Pollutant 8 (4), 31, 2013.

17. COOPER J.A., MORALES I., AMADOR J.A. Nitrogen transformations in different types of soil treatment areas receiving domestic wastewater. Ecological Engineering 94, 22, 2016.

18. BASSET N., KATSOU E., FRISON N., MALAMIS S., DOSTA J., FATONE F. Integrating the selection of PHA storing biomass and nitrogen removal via nitrite in the main wastewater treatment line. Bioresource Technology 200, 820, 2016.

19. ZHANGA M., LUOA P., LIUA F., LI H., ZHANGA S., XIAOA R., YINC L., ZHOUA J., WUA J. Nitrogen removal and distribution of ammonia-oxidizing and denitrifying genes in an integrated constructed wetland for swine wastewater treatment. Ecological Engineering 104, 30, 2017.

20. ZHAO B., TIAN M., AN Q., YE J., GUO J.S. Characteristics of a heterotrophic nitrogen removal bacterium and its potential application on treatment of ammonium-rich wastewater. Bioresource Technology 226, 46, 2017.

21. JENA, J., KUMAR, R., SAIFUDDIN, M., DIXIT, A., DAS, T. Anoxiceaerobic SBR system for nitrate, phosphate and COD removal from high-strength wastewater and diversity study of microbial communities. Biochem. Eng. J. 105, 80, 2016.

22. EUSEBI A.L., BELLEZZE T., CHIAPPINI G., SASSO M., BATTISTONI P. Influence of aeration cycles on mechanical characteristics of elastomeric diffusers in biological intermittent processes: Accelerated tests in real environment. Water Research 117, 143, 2017.

23. BONMATI A., FLOTATS X. Air stripping of ammonia from pig slurry: characterisation and feasibility as a preor post-treatment to mesophilic anaerobic digestion. Waste Management 23 (3), 261, 2003.

24. YANG Y., CHEN Z., WANG X., ZHENG L., GU X. Partial nitrification performance and mechanism of zeolite biological aerated filter for ammonium wastewater treatment. Bioresource Technology 241, 473, 2017.

25. SOLIMAN M., ELDYASTI A. Development of partial nitrification as a first step of nitrite shunt process in a Sequential Batch Reactor (SBR) using Ammonium Oxidizing Bacteria (AOB) controlled by mixing regime. Bioresource Technology $221,85,2016$.

26. OZDEMIR S., COKGOR E.U., INSEL G., ORHON D. Effect of extended aeration on the fate of particulate components in sludge stabilization. Bioresource Technology 174, 88, 2014.

27. ROSSO D., STENSTROM M.K., LARSON L.E. Aeration of large-scale municipal wastewater treatment plants: state of the art. Water Sci. Technol. 57 (7), 973, 2008.

28. FAN H., QIL L., LIU G., ZHANG Y., FAN Q., WANG H. Aeration optimization through operation at low dissolved oxygen concentrations: Evaluation of oxygen mass transfer 
dynamics in different activated sludge systems. Journal of Environmental Sciences https://doi.org/10.1016/j. jes.2016.08.008. [In press].

29. KARKARE M.V., MURTHY Z.V.P. Kinetic studies on agrochemicals wastewater treatment by aerobic activated sludge process at high MLSS and high speed agitation. Journal of Industrial and Engineering Chemistry 18, 1301, 2012.

30. MAKWANAA A.R., AHAMMED M.M. Continuous electrocoagulation process for the post-treatment of anaerobically treated municipal wastewater. Process Safety and Environmental Protection 102, 724, 2016.

31. CARTAGENA P., EL KADDOURI M., CASES V., TRAPOTE A., PRATS D. Reduction of emerging micropollutants, organic matter, nutrients and salinity from real wastewater by combined MBR-NF/RO treatment. Separation and Purification Technology 110, 132, 2013.

32. KATSOYIANNIS I.A, PETROS GKOTSIS P., CASTELLANA M., CARTECHINI F., ZOUBOULIS A.I. Production of demineralized water for use in thermal power stations by advanced treatment of secondary wastewater effluent, Journal of Environmental Management 190, 132, 2017.

33. MAZLUM S. Design and operational control of suspendedgrowth reactors and recovery of nutrients under variable flow conditions. Fresenius Environmental Bulletin 12 (10), $1180,2003$.

34. BAO T., CHEN T.H., QINNG C., XI J.J., FROST L.R. Development and application of palygorskite porous ceramsite in a biological aerated filter (BAF). Desalin. Water Treat. 57, 107, 2016.

35. BAO T., CHEN T.H., TAN J.W.M.L., ZHU D., CHEN D., XI Y.F. Synthesis and performance of iron oxide-based porous ceramsite in a biological aerated filter for the simultaneous removal of nitrogen and phosphorus from domestic wastewater. Separation and Purification Technology 167, 154, 2016.

36. HUANG W., ZHENG B., JIANG X. Effect of ionic strength on phosphorus removal with modified sediments in lake: kinetics and equilibrium studies. Int. J. Electrochem. Sci., 11, 9972, 2016.

37. DEBIK E., DEMIR, A., TOROZ I., GUNAY A. Investigation of chemical treatability of effluent water in IstanbulBaltalimani preliminary mechanical treatment plant. Fresenius Environ. Bull. 8 (5-6), 337=, 1999.

38. DEBIK E., DEMIR A., GUNAY A.The chemical treatability of municipal wastewater. Fresenius Environmental Bulletin 9 (7), 451, 2000. 